\title{
AOR
}

Selected Papers of \#AolR2021:

The 22nd Annual Conference of the

Association of Internet Researchers

Virtual Event / 13-16 Oct 2021

\section{FRAMING COVID-19: HOW FACT-CHECKING CIRCULATES ON POLITICAL FACEBOOK}

\author{
Raquel Recuero \\ MIDIARS Laboratory \\ Universidade Federal de Pelotas/Universidade Federal do Rio Grande do Sul (Brazil)
}

\section{Introduction}

Brazil is one of the worst-affected countries by Covid-19 in the world, with a record of 4000 deaths a day by April of $2021^{1}$. The gravity of the situation was partially attributed to the lack of coordination of the Health Ministry and the denial of the pandemic by Brazilian far-right president Jair Bolsonaro (Alcantara \& Ferreira, 2020). Disinformation on social media was also connected to Bolsonaro's political framing of the pandemic, which may have been key to its spread and gravity in the country (Soares et al., 2021). While there are also several fact-checking outlets in the country to combat this phenomenon, it seems they were unable to mitigate it. In this context, we discuss how political framing influences the circulation of fact-checking posts about the Covid-19 pandemic on Facebook's pages/groups in Brazil.

\section{Theoretical Background}

The political framing of the content connected to the Covid-19 pandemic is important because the tendency to receive or share disinformation has been linked to political affiliation. Calvillo et al. (2020), for example, found a connection between conservative ideological views and the difficulty to discern between disinformation and real content. Clarke et al. (2021), another example, found connections between political affiliation with the right-wing and the negative response to Covid-19 mitigation efforts. In Brazil, Rossini \& Kalogeropoulos (2021) found similar results.

Fact-checking has been one of the important tools to mitigate the spread of disinformation and particularly, during the Covid-19 pandemic for many countries (Lópes-Garcia, Sánchez \& Visozo, 2021). However, studies have shown that despite having a positive effect on the disinformation perception (Walter et al., 2019), fact-checking content often

\footnotetext{
${ }^{1}$ https://www.theguardian.com/world/2021/apr/07/brazils-coronavirus-death-toll-passes-4000-a-day-forfirst-time

Suggested Citation (APA): Recuero, R. (2021, October). Framing Covid-19: How facr-checking circulates on political Facebook. Paper presented at AolR 2021: The 22nd Annual Conference of the Association of Internet Researchers. Virtual Event: AolR. Retrieved from http://spir.aoir.org.
} 
doesn't circulate in the same spaces as disinformation (Recuero, Soares \& Zago, 2021), when they do, it is often connected with accusations against fact-checkers (Shao et al., 2018) and their circulation is biased by partisanship (Shin \& Thorson, 2017).

\section{Methods}

In this research, we aim to discuss how the political framing of fact-checking posts about Covid-19 may influence their circulation on Facebook Pages and Groups. Our research is based on a dataset of 460 fact-checking posts published on politically aligned Brazilian Facebook pages/groups that also published disinformation (312 with the right-wing and 149 with the left-wing). Data was obtained through IFCN/Poynter (International FactChecking Network).

To analyze these posts, we used frame analysis and particularly, Tannen's $(1986,2009)$ notion of "interactive frames". We categorized two sets of frames: The macro- frame (the page/group where it was originally shared and how it provides context for interpretation of the posts) and the strategies used on the micro-frame (how the fact-checking content was framed on the post itself). In this category, based on data from the posts, we identified three sub-framing strategies: (1) Confirmation framing, when the content was shared with other discourses that confirmed the post content and connected this content to the macroframing; (2) accusation framing, when the content was shared through an accusatory tone, often connecting the post content with an opposite political view; (3) discussion framing, when the post content was shared through a questioning/in doubt framing.

\section{Results}

Table 1 presents a summary of the results.

Table 1: Summary of results

\begin{tabular}{|l|l|l|l|l|}
\hline & Macro-frame & Micro-frame & & \\
\hline & Pages/Groups & $\begin{array}{l}\text { Confirmation } \\
\text { framing }\end{array}$ & $\begin{array}{l}\text { Accusation } \\
\text { framing }\end{array}$ & $\begin{array}{l}\text { Discussion } \\
\text { framing }\end{array}$ \\
\hline Right wing & $\begin{array}{l}\text { Pro-Bolsonarop (56) } \\
\text { Conservatives (12) } \\
\text { Military Intervention (6) } \\
\text { Other groups/pages (21) }\end{array}$ & 174 posts & 33 posts & 4 posts \\
\hline & $\begin{array}{l}\text { Pro-Lula (27) } \\
\text { Workers' Party (3) } \\
\text { Anti-Bolsonaro (6) } \\
\text { Other groups/pages (11) }\end{array}$ & 141 posts & 8 posts & 0 posts \\
\hline
\end{tabular}

Our data present interesting results. First of all, groups/pages that circulate fact-checking posts on this dataset are mostly affiliated with the right-wing (Shin \& Thorson, 2017). Other studies have shown that right-wing and conservative views are often more connected to disinformation than the left (Calvillo et al.; 2020, Alcott et al., 2020; Rossini \& Kalogeropoulos, 2021; Clarke et al., 2021), thus, a different result. However, the factchecking content that circulates among these right-wing groups is subjected to framing strategies that subvert their meaning to conform to a pro-Bolsonaro discourse. Accusation framing was also used to frame fact-checking as false or misleading content to support conspiracies, supporting Bolsonaro's claims of persecution by the media. Only a few posts would actually defy the page's ideology (though "discussion framing"). Leftist

Suggested Citation (APA): Recuero, R. (2021, October). Framing Covid-19: How facr-checking circulates on political Facebook. Paper presented at AolR 2021: The 22nd Annual Conference of the Association of Internet Researchers. Virtual Event: AolR. Retrieved from http://spir.aoir.org. 
groups shared more plural content of fact-checking and also used confirmation framing strategies but in a different way. Their framing was connected to support the fact-checking content itself. This may be because much of the fact-checking links would discredit Bolsonaro's discourse. Accusatory posts were connected to anti-Bolsonaro content.

These results are similar to what was discussed by other studies (Soares et al., 2021) that argued that disinformation about the pandemic in Brazil was strongly connected to the support of Bolsonaro. However, this research shows that fact-checking does circulate on political Facebook groups/pages that share disinformation (particularly on right-wing and conservative ones), but it is used to reinforce their discourse, rather than debunk it.

\section{References}

Alcantara, J., \& Ferreira, R. (2020). A infodemia da "gripezinha": uma análise sobre desinformação e coronavírus no Brasil. Chasqui. Revista Latinoamericana de Comunicación, 1(145), 137-162. https://doi.org/10.16921/chasqui.v1i145.4315.

Allcott, H., Boxell, L., Conway, J., Gentzkow, M., Thaler, M., \& Yang, D. (2020). Polarization and public health: Partisan differences in social distancing during the coronavirus pandemic. Journal of public economics, 191, 104254. https://doi.org/10.1016/j.jpubeco.2020.104254

Calvillo, D. P., Ross, B. J., Garcia, R. J. B., Smelter, T. J., \& Rutchick, A. M. (2020). Political Ideology Predicts Perceptions of the Threat of COVID-19 (and Susceptibility to Fake News About It). Social Psychological and Personality Science, 11(8), 1119-1128. https://doi.org/10.1177/1948550620940539.

Clarke, E., Klas, A., \& Dyos, E. (2021). The role of ideological attitudes in responses to COVID-19 threat and government restrictions in Australia. Personality and individual differences, 175, 110734. https://doi.org/10.1016/j.paid.2021.110734

CrowdTangle Team (2021). CrowdTangle. Facebook, Menlo Park, California, United States. URL: https://apps.crowdtangle.com/search/

López-García, X.; Costa-Sánchez, C.; Vizoso, Á. (2021)Journalistic Fact-Checking of Information in Pandemic. Stakeholders, Hoaxes and Strategies to Fight Disinformation during COVID-19 Crisis in Spain. Int. J. Environ. Res. Public Health 2021, 18, 1227. https://doi.org/10.3390/ ijerph18031227

Recuero, R., Soares. F. \& Zago, G. (2021) Polarização, Hiperpartidarismo e Câmaras de Eco: Como circula a Desinformação sobre Covid-19 no Twitter. Ahead of print. Revista Contracampo. https://periodicos.uff.br/contracampo/article/view/45611

Rossini, P., \& Kalogeropoulos, A. (2021). News and (Mis)information about COVID-19 in Brazil. Research Report, University. https://www.liverpool.ac.uk/media/livacuk/schoolofthearts/documents/communicationan dmedia/Rossini,Kalogeropoulos,Report,insights,07122020.docx.pdf 
Shao, C., Hui, P., Wang, L., Jiang, X., Flammini, A., Menczer, F., \& Campaglia, G. L. (2018). Anatomy of an online misinformation network. PLoS One 13(4): e0196087. https://doi.org/10.1371/journal.pone.0196087

Shin, J. \& Thorson, K. (2017). Partisan Selective Sharing: The Biased Diffusion of FactChecking Messages on Social Media. Journal of Communication 67(2), 233-255. https://doi.org/10.1111/jcom.12284

Soares, F. B., Recuero, R., Volcan, T., Fagundes, G., \& Sodré, G. (2021). Research note: Bolsonaro's firehose: How Covid-19 disinformation on WhatsApp was used to fight a government political crisis in Brazil. Harvard Kennedy School (HKS) Misinformation Review. https://doi.org/10.37016/mr-2020-54

Tannen, D. (1986) Frames Revisited. QUADERNI DI SEMANTICA / Vol. VII, no. 1, June 1986.

https://static1.squarespace.com/static/5523ffe4e4b012b2c4ebd8fc/t/56d9c77f1bbee076 a4c276ae/1457112959138/frames+revisted.pdf

Tannen, D. (2009). Framing and Face: The Relevance of The Presentation of Self to Linguistic Discourse Analysis. Social Psychology Quarterly, 72(4), 300-305. https://doi.org/10.1177/019027250907200404

Walter, N., Cohen, J., Holbert, L, \& Morag, Y. (2019). Fact-Checking: A Meta-Analysis of What Works and for Whom. Political Communication 37(3): 350-375. https://doi.org/10.1080/10584609.2019.1668894. 